\title{
'Speaking' racism and anti-racism: perspectives of local anti-racism actors
}

J.K. Nelson

\begin{abstract}
'Speaking' racism is the explicit use of the terms racism and anti-racism, rather than more palatable or 'positive' alternatives. To address racism, using the language of racism and antiracism is critical, as it acknowledges the presence of racism and, in doing so, overcomes denial. Dispositions to speaking racism and anti-racism are positioned within the historical context of racism and the discourse of tolerance in Australia. Interviews with individuals working in local anti-racism in two sites were the primary data source for exploring dispositions to the language of racism and anti-racism. Reticence to speak racism was prevalent, largely driven by fear of inducing defensiveness and sensitivity to the highly emotive nature of racism. A similar ambivalence around the term anti-racism was found, in line with the 'positive turn' in anti-racism policy. Alongside this discomfort some local antiracism actors recognised the role speaking racism could play in challenging denial.
\end{abstract}

Keywords: Racism; anti-racism; denial; discourse; Australia; local government 
While conducting a research project on local anti-racism in Australia, I observed firsthand the emotive nature of the language of racism and anti-racism. This paper explores the challenges associated with 'speaking' racism and anti-racism, understood here as explicit use of the terms racism and anti-racism, rather than more palatable or 'positive' alternatives. The paper is premised on the assertion that if we are to address racism using the language of racism and anti-racism is critical, as it clearly acknowledges the presence of racism and, in doing so, overcomes denial. I posit that dispositions to speaking racism and anti-racism need to be positioned within the historical context of racism in Australia, and amongst the discourse of tolerance that is pervasive in Australia and other Western democracies. I look at what social science tells us constitutes efficacious anti-racism, arguing that 'speaking' racism enables a broad range of action analogous to my framework for effective antiracism. The second part of the paper examines local anti-racism actors' use of the terms racism and anti-racism, covering both the reticence to speak racism as well as the recognition of the benefits of speaking racism and anti-racism.

\section{The case for 'speaking' racism}

Many commentators have made the assertion that the Australian nation has a racist foundation, citing the colonial British invasion which displaced Aboriginal occupants from lands they worked and adapted for millennia and the subsequent treatment of Aboriginal and Torres Strait Islanders (e.g. Jayasuriya 2002; Nelson and Dunn 2013). In 1901, the Immigration Restriction Act was passed as the first order of legislative business for the newly formed Federal Parliament of Australia, designed to exclude non-White races from Australia. The White Australia policy, as it was also known, would remain in place until the 1970s (Nelson and Dunn 2013). This history reveals two axes of Australia's racist past: Indigenous and non-Indigenous relations in a settler colonial nation and white nonwhite/migrant relations. In the 1990s a formal political process of reconciliation between Indigenous and non-Indigenous Australians began. A key milestone in the reconciliation agenda was the 2008 national apology by Prime Minister Kevin Rudd for the removal of Aboriginal children from their parents during the assimilation period. The extent to which the reconciliation process has addressed 
the core issue of colonial dispossession is limited, and there remains a feeling that the reconciliation movement asks Aboriginal Australians 'to reconcile themselves to dispossession without an attendant move from non-Indigenous Australians' (Nelson and Dunn 2013, 263). Similarly, in regards to Australians of diverse ethnic or migrant backgrounds, the dismantling of the White Australia policy led the way to the development of multicultural policies, designed to celebrate cultural diversity, ensure access and equity, and promote an inclusive national identity. Steps like the reconciliation process and multicultural policies are only a starting point for addressing the profound history of racism in Australia and much remains to be done to address its ongoing effects.

Alongside the historical and continued presence of racism in Australia sits a discourse of tolerance, which posits that Australian society is built on tolerance (Hage 1998). Hage is one of the strongest critics of the idea of tolerance, describing it as an exercise in spatial management. He argues that the dominant White culture has an interest in advocating tolerance, as this framing puts White Australians in control of national space. 'If 'racist violence' is better understood as a nationalist practice of exclusion, 'tolerance', in much the same way, can be understood as a nationalist practice of inclusion. Both, however, are practices confirming an image of the White Australian as a manager of national space' (Hage 1998, p.90-91). Outside of the Australian context, working in the Netherlands and United States, Essed (1991) describes a myth of tolerance and the way it undermines anti-racism. 'If the reality is defined as a reality of tolerance, there is no legitimate basis for opposition to racism' (Essed 1991, p.115). The language of tolerance has faced critique both in Australia and elsewhere, for the ability to tolerate is retained by the powerful, leaving minority groups to hope they will be tolerated (Blommaert and Verschueren 1998; Hage 1998). The critique of tolerance has had policy traction in Australia, with government organisations like VicHealth calling for strategies that are about 'More than Tolerance' (Paradies et al. 2009). Balint (2006; 2010; 2013) has presented a strong challenge to the distaste for the language of tolerance, preferring it to alternatives like respect. Balint (2010) argues that tolerance is a minimal condition for people with diverse ideological, religious, and other beliefs, in proximate spaces, and asserts that the boundaries of tolerance are far broader than the boundaries of respect. 
The discourse of tolerance is made possible by denying racism. The denial of racism is a central feature of modern racism, and manifests at both an individual and a political level, present in Australia and throughout the West (see, for example, van Dijk 1992; Wetherell and Potter 1992; Augoustinos and Every 2007; Dunn and Nelson 2011; Nelson 2013a). Political denial of racism in the Australian context is evident in the recent harmony agenda. The Howard Government implemented the Living in Harmony programme in 1996, at its outset 'an anti-racism education and awareness campaign' (Australian Government Department of Immigration and Multicultural Affairs 1998, p.2), but the programme quickly took a 'positive turn' (citing Goldberg, Lentin 2008, p.313), with anti-racism subsumed into a 'harmony' agenda. Within this framework the language of racism and anti-racism was avoided. The harmony agenda was associated with particular types of antiracism. Ho (2009) discusses Lentin's idea of the positive turn in Australia as a focus on celebratory initiatives, that emphasise commonalities between diverse groups, rather than policies and programmes that seek to understand and disrupt continued experiences of racism. In line with this positive turn, under the Howard Government the United Nations International Day for the Elimination of Racial Discrimination became 'Harmony Day' in Australia. The Gillard Government launched an anti-racism strategy in August 2012 and this strategy broke from the past by directly engaging the language of racism and anti-racism. However, from the late 1990s until 2012, antiracism initiatives were largely framed in terms of harmony. This framing contributes to the discourse of tolerance and does little to challenge the legacies of racism and contemporary experiences of racism in Australia.

The discourse of tolerance is not limited to Australia. Goldberg (2002) and Lentin (2008) observe the positive turn in anti-racism policy in the United States and Europe respectively. In the United Kingdom the discourse of tolerance is strongly reflected in the community cohesion agenda (Cheong et al. 2007). According to this policy framework, the remedy to interethnic tension is strengthening community ties and shared values, rather than addressing racism (Worley 2005). The community cohesion agenda, much like the harmony agenda in Australia, fails to face up to racism. 
Political denial of racism in Australia can be found in government responses to specific incidents of racism, including the Cronulla riots and the much publicised violent attacks on Indian students. Following the Cronulla riots on a Southern Sydney beach in 2005, Poynting (2006) interrogated then Prime Minister John Howard's refusal to use the 'r' word. In a key address following the Cronulla riots Howard stated he did 'not accept there is underlying racism in this country' and warned the Australian public it would be an 'enormous mistake if we began to wallow in generalised self-criticism' (Howard 2005, p.1-2). Howard constructs public debate and critical reflection about racism as unnecessary and unproductive. Denial was also the dominant political response to the attacks on Indian students in mid-2009 (Dunn et al. 2011). It was only when the income derived from the international education sector, Australia's fourth largest national export, appeared under threat, that political responses shifted from denying racism to emphasising the government's intolerance of racist violence and the strength of their response. Failing to speak racism in policy and in response to incidents of racism narrows the range of possibilities for antiracism (Nelson 2013b).

The literature that directly examines what constitutes efficacious local anti-racism is relatively sparse (Paluck and Green 2009). However, my reading of the literature suggests that effective antiracism must have a broad reach, addressing not only what psychologists and sociologists have termed 'old' and 'new' racisms (Walker 2001), but also the sense of loss sometimes attached to discussions of demographic change; denial of racism; and acknowledgment of white privilege. 'Old' racism is blatant and hostile (Walker 2001), while 'new' or 'modern' racism is subtle and unconscious (McConahay 1986), focusing on asserted incompatible cultural difference rather than racial hierarchies (Jayasuriya 2002). Anti-racism needs to be responsive to both traditional and 'new' forms of racism, based not on colour, but on culture (Modood 1997) and religion (Vasta 2007, p.31). Anti-racism must also address the sense of loss for majority group members that is sometimes associated with diversity and policies of multiculturalism (e.g. Hage 1998; Vasta 1996; Ang 2000), as this can be an antecedent to racism. Vasta (1996) argued that '...Anglo Australians have benefitted from that dominant Anglo 
identity, whether they are racist or not. This sense of loss is not itself racist, but it can often be expressed through racist discourse and practices' (p.56).

The prevalence of denial, discussed earlier, suggests that a key task of anti-racism is to establish itself as a legitimate, necessary activity. Overcoming denial involves education on what constitutes racism. Racism must be understood as more than an individual affliction, suffered by 'ignorant', working class, white people (Ang 2000). Recognising that racism is embedded in cultural and institutional practices structures how we do anti-racism. One form of denial is 'deflections from the mainstream' (Nelson 2013b), whereby the problem of racism is located within a small, aberrant pocket of the population. If racism is contained to an aberrant few, speaking racism in relation to racist cultural or institutional practices becomes challenging.

Another key task of anti-racism is increasing recognition of white privilege. Anti-racism must move beyond racist acts, 'racists', and material inequality, to encompass questions about privilege and white hegemony (Green et al. 2007; Sefa Dei 1996). Along these lines, anti-racism could involve challenging individuals to see how they are personally implicated or benefit from racist practices, that they are not located outside of racism (O'Brien 2009). Green and Sonn (2006) argue that 'simply not recognising whiteness within anti-racism practice reproduces its power' (p.382). Effective anti-racism needs to focus on more than racist attitudes, and challenge the primacy of white Australia in constructions of national identity.

Efficacious anti-racism must be broad ranging, and utilise a wide range of strategies. Dunn et al. (2001) classified anti-racism by local government in Australia as being either celebratory, hosting festivals and facilitating diverse cultural activities, or regulatory, addressing racism and local tensions. A third goal of local anti-racism is educative. In both the current study and Dunn et al. (2001) celebratory initiatives were the most common anti-racism strategy used at a local level, initiatives which typically involve bringing people of varied ethnic backgrounds together in an enjoyable setting, or exposing Anglo Australians to the culture of non-Anglo 'others' (Dunn et al. 2001). These initiatives are premised on the idea that interethnic contact reduces prejudice. Celebrations of diversity have been heavily critiqued in the literature, for stereotyping and commodifying otherness 
(Jordan and Weedon 1995; Poynting and Mason 2008; Mansouri et al. 2007; Kymlicka 2010), as well as failing to address racism (Rothenberg 2000; Babacan and Hollinsworth 2009) and economic and political inequalities (Kymlicka 2010; Marotta 2006). Celebrations play an important role, however, in promoting inclusive conceptions of national identity, and some authors have argued that food related celebrations, for example, can offer much more than a 'touristic' approach to diversity (Richardson 2011). Celebrations may cross over into the realm of education, but cannot regulate against racism. If we think back to the key tasks of efficacious anti-racism, for example, confronting denial and questioning white privilege, it is clear that other forms of anti-racism are needed alongside celebrations. As I present the interview data below, I reflect on why celebratory anti-racism was predominate in the localities I studied and provide commentary on how 'speaking' racism and antiracism relates to local action.

\section{'I just don't like the word racism': reticence to 'speak' racism}

The findings reported here are based on a research project about local anti-racism in Australia, within which 22 interviews were conducted with individuals working on local anti-racism in two case study areas (in New South Wales and South Australia) and a further eight interviews were undertaken with those working in anti-racism at a state or federal level. Reticence to speak racism was expressed by participants from varied gendered, racial and organisational positionings. The level at which an interviewee worked was the strongest predictor of willingness to speak racism, with the greatest reluctance found amongst those working at a local level. One explanation for this resistance is that local interviewees were engaged in a process of place defending, protecting their locality from being branded a racist space, an explanation discussed in detail elsewhere (Nelson in press). An alternative explanation, elaborated below, was that, for participants working at a local level, their work role structured their willingness to speak racism.

Even among this specialist group who were heavily involved in interethnic community relations, discomfort with the term racism was common. For a small minority of participants, discomfort was rooted in denial of racism. I refer to this as an absence discourse (Nelson 2013b). 
Camille exercised caution when talking about racism, because she believed that false claims of racism were deployed by some people to 'get a benefit or get out of trouble'.

Oh we do, but we have to be very careful with it because... sometimes members of the community use racism as a way to get a benefit or get out of trouble. [Describes example of a large African family being refused rental accommodation and claiming discrimination]. So we have to be very careful because it's quite easy to use racism as the scapegoat for a lot of things, and... actually, I don't think there's racism in Australia... it may be hidden, but not you know overtly. [Camille, community organisation, NSW]

While it was unclear whether or not there was racism in the example Camille provided, there are reports of discrimination in the rental housing market in Australia (Equal Opportunity Commission of Western Australia 2009; Human Rights and Equal Opportunity Commission 1991) and so the concerns of discrimination from the African family may well have been reasonable. Camille undermined these claims to racism. While making attributions to racism is a complex process (see, for example, Major et al. 2002; Stangor et al. 2003), reporting experiences of discrimination may be painful (Schmitt and Branscombe 2002), and international research indicates that individuals are more likely to under rather than overestimate experiences of racism (Kaiser et al. 2006; Mellor et al. 2001; Sechrist et al. 2004). Camille's claims then that the groups she works with routinely use racism to their own advantage appear weak in light of this literature. In her denial, Camille discredited and pathologised those who made claims of racism (Essed 1991). The idea that racism is used to 'get a benefit' has strong parallels with the discourse of 'special treatment' associated with Aboriginal Australians, beliefs that Aboriginal people receive excessive government benefits and assistance compared to non-Aboriginal members of the community (Pedersen and Barlow 2008; Pedersen et al. 2000).

The defensiveness the term racism could induce was a reason to be cautious. Nerida, Rosa and Pejna, below, felt if used inappropriately, the term racism could be counterproductive.

Personally, very comfortable. In my position I would be really careful about using it because I think that it alarms people and alienates people. [Later] There's also part of me that thinks, you know I'm hesitating now because even though I am comfortable, I think if you use the term 
racism it can be used to stop looking at what the issues really are. [Nerida, local government, NSW]

If you can use it to shock them and then let them hear what you've got to say, then it's good. But if it's going to be, well no that doesn't exist, then that's not useful 'cause you've closed down the conversation and you're not going to get anywhere. We talk about it internally but... [Rosa, community organisation, NSW]

When I first started I used racism a lot but I came to a point that people are a little bit kind of afraid whenever they hear racism it's something big so I started to replace... I started to replace with a multicultural approach as like the flip side of... and then people are more interested in doing and talking. But if it's racism it's a little bit - people who experience racism, they jump on the word and they talk about it. But mainstream doesn't like that. So I'm not using it as much as I used to use it. [Pejna, community organisation, NSW]

Participants were ambivalent about the term racism and its appropriate use. Nerida first claimed to be 'very comfortable' with the term in her own personal life, but more cautious in her professional role. She then questioned herself, expressing concern that using the term racism can stymie further investigation of complex issues. Nerida's reluctance to use the term racism may relate to the dominant understanding of racism as an individual level problem, and reflect that in everyday conversation a discussion of racism tends not to be about racist cultural and institutional practices.

Nerida and Pejna were wary of alienating people, while Rosa worried that the term closed down conversation. All three interview participants recognised the power of the term, reflecting that ‘it's something big' (Pejna), it 'alarms people' (Nerida) and 'you can use it to shock them' (Rosa). If the intention is to challenge privilege, using the term racism may be acceptable, with the right people in the right setting. The delicacy of negotiating racism at an interpersonal level has been raised in the literature (Guerin 2005; Pedersen et al. 2011). Individuals may be inhibited from responding to racism by perceived risks to interpersonal relationships (Hyers 2007; Scully and Rowe 2009).

Nerida explicitly makes a distinction between speaking racism in her personal and professional lives. In all three accounts Nerida, Rosa and Pejna's caution about speaking racism is strongly related to their positioning within their organisations. Pejna traced her use of the term racism, stating that 
when she first began working in interethnic community relations she used the term a lot, but her language use changed over time to engage with her 'mainstream' colleagues. The regulation of racism was palpable in these participant accounts, as they struggled to find appropriate language to talk about negative orientations to difference. Living with difference need not necessarily always be about harmony or unity, and it may be that creating space for difference means engaging with disagreements, contestation and conflict (Balint 2006; Balint 2010). Part of creating space for difference is about having access to language that engages with these issues.

The desire to focus on positives or strengths, rather than racism, was common among local interview participants. Although Rosa, the manager of a community organisation in NSW, saw speaking racism as important in general (discussed below), when it came to her local area, she had an interest in highlighting its strengths, rather than talking about racism. Kim similarly explained why the language of diversity was preferred to that of racism.

...the other thing is that we try to talk about strengths based and we try to say that we are a strengths based organisation - so to acknowledge that the people in our area are probably more racist than anybody else - it's probably not something that we want to highlight. We would be wanting to say we want - the diversity in our area is fabulous... [Rosa, community organisation, NSW]

Racism is a horrendous thing, you know, and people who experience any form - particularly blatant racism - it's horrendous. Diversity, on the other hand, is exciting and positive. [Kim, local government, SA]

Reticence to speak racism was linked to characterisations of Australians as tolerant. Participants working at a state or federal level were able to provide a more macro view of racism, and in doing so provided commentary on the discourse of tolerance that they saw as pervasive in Australia.

I think that part of almost a cultural trait of Australians is to say, we're a very tolerant people and there are pockets of racist behaviour - we're not racist. [Dieter, federal government] ...there's this idyllic view that people like to have of Australia that we're not a racist country. So calling it racism is a bit sort of challenging that. I mean, our leaders will say, oh we have zero 
tolerance of racism in Australia... But they're not prepared to go the next step and say, and that particular action is racism. [Ian, federal government]

Dieter linked tolerance with Australian identity, and asserted that the discourse of tolerance was so prevalent that it could almost be considered a 'cultural trait'. Ian referred to the way political leaders state they have 'zero tolerance' of racism (see, for example, Dunn et al. 2011), yet are not prepared to admit an instance of racism. The claim to zero tolerance becomes empty if the existence of racism in a given situation is not acknowledged.

\section{Racism as a 'clue term': benefits of 'speaking' racism}

Alongside the discomfort and ambivalence was a strong recognition, in some interviews, of the advantages of using the term racism. While acknowledgment of the benefits of speaking racism was higher amongst participants working at a state or federal level, some local participants, like Simon, strongly argued for speaking racism.

Oh yeah, we use the word racism, we use the word discrimination. We use the word invasion and settlement. Invasion and settlement. Because they're clue terms, they explain the processes collectively what happened. [Simon, school principal, SA]

Simon related the term racism to the term invasion, a word used to describe the arrival of the British in Australia. The appropriateness of describing the arrival of white settlers as an invasion has been a matter of debate amongst historians and educators in particular (Veracini 2003; Augoustinos et al. 1999; Augoustinos et al. 2002). The discourse of invasion has also been used to describe Asian migration to Australia (Jupp 1998), and more recently asylum seeker arrivals in Australia (Every and Augoustinos 2008). Simon also used the word settlement, suggesting that he was taking a middle ground with language. Simon considered the term racism as controversial and potentially divisive as the word 'invasion' had been. He recognised the importance of language, however, describing these concepts as 'clue terms', arguing that the use of these particular words, rather than alternatives, begins to explain real events and circumstances. Schools appeared to be more willing than other local 
institutions to speak racism. For example, another school principal talked about anti-racism being a natural and essential component of the curriculum, akin to anti-bullying.

Speaking openly about racism was seen as an important step in addressing it by half of the state/federal interview participants, and, to a lesser extent, local participants (4 of 22).

I try and name it 'cause I think people are frightened to talk about it... But I think until we challenge people I think you have to name it. [Brigid, state government] Brigid acknowledged the reluctance to speak about racism, but argued it needs to be named. Individual and public acknowledgment of the presence of racism importantly challenges denial. Interview participants working at the state/federal levels were more comfortable speaking about racism than local interview participants. My interview with a senior federal bureaucrat, Richard, took place shortly after the Federal Government released their new Multicultural Policy (Australian Government 2011). The policy was significant in that it made direct reference to racism, unlike earlier policy documents, and included plans for a National Anti-Racism Strategy. It was in this context that I asked Richard about using the term racism in his work.

I do, but I know that um, there has been a hesitancy in government to use that term for some time and it was quite a breakthrough that in the new policy they used the term... But basically I think it's very hard to solve a problem if you don't recognise the problem.

[Later] ...you can talk about harmony and no one can necessarily make the link that you're talking about racism. [Richard, federal government]

Richard acknowledged the previous absence of the term racism from government language, and stated that naming racism signified 'a significant change in direction'. Speaking racism in the recent Multicultural Policy was a conscious decision by the Australian government, and previously not using the term was an equally strategic decision. Richard recognised that 'the use of the term is important'. Unsurprisingly, talking about harmony and understanding does not clearly communicate an interest in addressing racism. 


\section{'Our big problem is the word': 'speaking' anti-racism}

Ambivalence was not limited to the term racism; participants were equally if not more ambivalent about the term anti-racism. Again, there was more reluctance to speak anti-racism at a local compared to state/federal level. There was no consensus on words that were preferred, though alternatives included harmony, integration, understanding and respect. As tools to combat racism, these alternatives all conceptualise racism as an individual pathology. A review of the Living in Harmony programme recommended that anti-racism initiatives and messaging should be 'subtle, non threatening, positive, apolitical, engaging, encouraging, warm, optimistic and non dictatorial' (Australian Government Department of Immigration and Citizenship 2009, p.6). Very strong antiracism messages were seen as alienating and therefore potentially counterproductive. This view of anti-racism was evident in the way interview participants spoke about local anti-racism.

Sophia (NSW) described anti-racism as 'a brave word' but felt it was a lofty aim. Other participants were critical of the word itself, and the implications of using it.

Now our big problem is the word. We don't like the word anti-racism at all because that implies that there is racism already. We'd never use that word and I've never used it even [in other workplaces directly looking] at these sort of things. I guess I'd like a positive word rather than a negative. [Later] Anti-racism assumes always that there is something happening out there that we're trying to stop. What I'd rather have is some strategies around including people into something that's positive. [Karla, local government, SA]

Karla objected to the term anti-racism because it implied there was racism. This fundamental objection, though not stated as explicitly by other participants, was pervasive, particularly in local participants' discussions of anti-racism. Advocating a strengths based model, as Karla did, was common among the interview participants. Karla expressed genuine concerns about positive action. But if we think about orientations to difference, this approach only allows for positive orientations. Replacing anti-racism with a positive term is likely to lead to a predominance of celebratory initiatives, and this was the case in the local areas under study. The direction of influence is unclear: language may proceed action, action may influence language, or, most likely, both of these processes 
are occurring in tandem. Talking in terms of anti-racism, in my view, would allow for a wider range of anti-racism activity, such as raising awareness of white privilege and addressing systemic racism. Speaking anti-racism, rather than harmony or respect, for example, may pave the way for action targeted at racist cultural and institutional practices, programmes that go beyond educating the 'racist' individual.

Rosa similarly avoided the term anti-racism, arguing that people were more comfortable with positive terms.

Um, I think people are probably more comfortable with - although harmony's sort of lost its positive spin too now, but you know those sort of terms about celebrating diversity and those sort of - rather than anti-racism. [Rosa, community organisation, NSW]

The transience of terminology in interethnic community relations is evident here. Rosa acknowledged that harmony, while once popular, 'has lost its positive spin too now'. Ho and Dreher (2006) documented the shift in terminology in the early 2000s in Australia, from racism to harmony. We get the sense of an endless search for language most appropriate to capture and describe the issues. This may be an ongoing effect of discourses of denial. Continual changes in language and the goals of local anti-racism have the effect of setting up moving targets, and debilitating local action. Deborah, manager of a community services organisation in South Australia, reflected that simply being asked about her use of the term harmony challenged her and prompted her to consider her discomfort with the language of anti-racism. Thomas, from the tertiary education sector in South Australia similarly said that even being asked about terminology challenged him and made him think 'there is a need to be more upfront with language'.

Kim talked about the need for language to be appropriate to a specific setting. I think that sometimes it depends on who you're actually addressing... I'm working on a project right at the moment which is looking at addressing some of the conflict between Aboriginal and African - particularly young males. Now... we talk about it as an anti-racism project. But the moment I'm out within a community - or even if I'm talking to elected members - the project is... turned from - into a positive connotation. [Kim, local government, SA] 
Privately, with colleagues, Kim discusses projects as anti-racism. In a public setting, she turns antiracism into 'a positive connotation'. Several interview participants spoke of their disparate use of language within their organisation and outside, in public settings. In this way, anti-racism was hidden from public view. Intuitively it seems sensible to be strategic about using the language of racism and anti-racism, as long as this can be done without the issue being silenced. The effect of using the words racism and anti-racism in varied settings requires further research.

Lorraine felt anti-racism worked best when the language of anti-racism was not used and the anti-racist intent of a project was hidden.

...nobody is labelling this in a heavy handed way as anti-racism, this is just a cultural festival that we do in our community as part of community development. I think that's such a good way of bringing it in, yeah.

[Later] Yeah, yeah, it's not branded as that and if you stopped the people who were going around the stalls and asked them about anti-racism they'd look at you blankly. You know, why are you bothering me about anti-racism when I'm having fun at a festival on a sunny day and I think that's just exactly the way to do it. [Lorraine, state government]

Lorraine described anti-racism as 'a heavy handed way' of characterising interethnic community relations projects. The anti-racism that she praised was mostly celebratory and about facilitating productive contact. However, celebratory anti-racism initiatives are only one component of a broad array of anti-racism tools needed to combat racism. Lorraine seemed critical of initiatives that more directly focus on addressing racism, yet putting people together in enjoyable settings has limited effects on racism (Allport 1954/1979; Pedersen et al. 2005; Pedersen et al. 2011).

Lorraine also referred to the 'branding' of interethnic community relations projects. This use of marketing language is an example of the way that social policy has been colonised by advertising discourse (Fairclough 1992). Presenting anti-racism in this way suggests that, in the current environment, anti-racism is something that needs to be sold to the public, and that we must determine the best way of 'packaging' anti-racism. But effective anti-racism may not always be palatable. It may be that at least some anti-racism needs to be confronting, and needs to make people 
uncomfortable. Future research needs to evaluate the effects of varying types of anti-racism campaigns over extended periods of time to determine the most effective tenor of anti-racism.

\section{Conclusion: local language of racism and anti-racism?}

Interview participants were ambivalent about the language of racism and anti-racism, more so at the local level than among those working at state/federal level. The underlying drivers of this ambivalence are not yet clear. I suspect that our desire to 'move on' from colonial dispossession and the overt racism of the White Australia policy period plays a central role in our collective affective response to the language of racism and anti-racism, but this assertion requires further research. Local anti-racism actors engaged with the language of racism and anti-racism in similar ways, in spite of the fact that the two case study areas were geographically distant, with different immigration histories and cultural demography. While participants acknowledged that using the term racism could be powerful and challenging, they were wary of its use for the same reasons. Alternatives to anti-racism like harmony, celebrating diversity, and welcoming programmes were preferred. These served to construct the problem of racism as operating at the level of the individual, rather than recognising the racism inherent in cultural and institutional practices. The preference for positive terminology left participants without the language to contemplate interethnic disharmony or conflict, yet acknowledging negative orientations is an important part of creating space for difference (Balint 2006; Balint 2010).

Local interview participants carefully regulated their use of the terms racism and anti-racism, fearing defensiveness and that using the language of racism and anti-racism might be counterproductive. It is difficult to know whether these beliefs came from experience using the terms, or was driven by public prohibitions around the language of racism and anti-racism. Future research could examine empirically the effects of varied terminology when confronting or attempting to address racism.

The preference for positive language amongst many local interview participants was paired with a predominantly celebratory approach to local anti-racism. It may be that national politics of 
anti-racism structure the conditions of possibility (Fairclough 2003) for local anti-racism. At a national level, the framing of anti-racism as about harmony and celebration, meant that local anti-racism projects were more likely to attract funding if they were 'branded' or 'spun' in this way. While celebrations are important in promoting inclusive conceptions of national identity, they must occur alongside other forms of anti-racism. This paper discussed the need for anti-racism to address 'old' and 'new' racisms, confront denial, address the loss sometimes associated with neighbourhood change, and raise awareness of white privilege. Local anti-racism should encompass celebratory, educative and regulatory initiatives. Currently programmes that raise questions about white privilege or provide opportunities for long term optimal contact, for example, need to be framed in positive terms to attract funding.

In both Australia and the United Kingdom government denial of racism and the depoliticising of anti-racism is common; there has been a 'sustained retreat' (Bloch \& Dreher 2009, p.197) from the language of anti-racism with programmes framed as 'harmony' or 'cohesion' initiatives. The extent to which these depoliticised policy frameworks can engage with the racist foundations of the Australian state and attendant social, educational, and economic inequalities is limited, and the core issues of colonial dispossession and white privilege remain firmly present. Despite state denial of racism, state and federal participants in this research, most of whom were public servants, readily acknowledged racism and the need for anti-racism. This may be related to the timing of the interviews, which took place shortly after the February 2011 announcement of a new Multicultural Policy (Australian Government 2011). The fact that this policy document openly acknowledged racism and included plans for an anti-racism strategy may have created some space for conversation about racism. Alternatively, it may be that people working on anti-racism, both at the state/federal and local levels, have highly developed critical literacy about anti-racism. For this engagement with racism to continue, speaking racism and anti-racism is critical, as it confronts denial and forces us to contemplate negative orientations to difference as well as positive ones.

\section{Acknowledgments}


The author would also like to thank Professor Kevin Dunn for his helpful comments on an earlier version of this manuscript.

\section{Funding}

This research was supported by an Australian Research Council Linkage Grant [LP0882860, Constructing regionally appropriate anti-racism strategies for Australia]. 


\section{References}

ALLPORT, GORDON 1954/1979 The Nature of Prejudice: 25th Anniversary Edition. Reading, Massachusetts: Addison-Wesley Publishing Company.

ANG, IEN 2000 'Identity blues', in Paul Gilroy, Laurence Grossberg \& Angela Mcrobbie (eds) Without Guarantees: In Honour of Stuart Hall. London, New York: Verso.

AUGOUSTINOS, MARTHA \& EVERY, DANIELLE 2007 'The language of "race" and prejudice', Journal of Language and Social Psychology, vol. 26, no. 2, pp. 123-141.

AUGOUSTINOS, MARTHA, LECOUTEUR, AMANDA \& SOYLAND, JOHN 2002 'Self-sufficient arguments in political rhetoric: Constructing reconciliation and apologizing to the stolen generations', Discourse \& Society, vol. 13, no. 1, pp. 105-142.

AUGOUSTINOS, MARTHA, TUFFIN, KEITH \& RAPLEY, MARK 1999 'Genocide or a failure to gel? Racism, history and nationalism in Australian talk', Discourse \& Society, vol. 10, no. 3, pp. 351 378.

AUSTRALIAN GOVERNMENT 2011 'The People of Australia: Australia's Multicultural Policy', in Department of Immigration And Citizenship (ed). Australian Government.

AUSTRALIAN GOVERNMENT DEPARTMENT OF IMMIGRATION AND CITIZENSHIP 2009 'Living in Harmony: Program Review.'. Canberra: Australian Government Department of Immigration and Citizenship.

AUSTRALIAN GOVERNMENT DEPARTMENT OF IMMIGRATION AND MULTICULTURAL AFFAIRS 1998 'Living in Harmony - An Overview'. Canberra: Department of Immigration and Multicultural Affairs.

BABACAN, HURRIYET \& HOLLINSWORTH, DAVID 2009 'Confronting Racism in Communities Project: A Final Report on the Nature and Extent of Racism in Queensland'. Paddington, Queensland: Centre for Multicultural Pastoral Care.

BALINT, PETER 2006 'Respect relationships in diverse societies', Res Publica, vol. 12, no. 1, pp. 35-57. BALINT, PETER 2010 'Avoiding an intolerant society: Why respect of difference may not be the best approach', Educational Philosophy and Theory, vol. 42, no. 1, pp. 129-141. 
BALINT, PETER 2013 'Against respecting each others' differences', Journal of Applied Philosophy, vol. 30, no. 3, pp. 254-267.

BLOMMAERT, JAN \& VERSCHUEREN, JEF 1998 Debating Diversity: Analysing the Discourse of Tolerance. London; New York: Routledge.

CHEONG, PAULINE HOPE, et al. 2007 'Immigration, social cohesion and social capital: A critical review', Critical Social Policy, vol. 27, no. 1, pp. 24-49.

DUNN, KEVIN M. \& NELSON, JACQUELINE K 2011 'Challenging the public denial of racism for a deeper multiculturalism', Journal of Intercultural Studies, vol. 32, no. 6, pp. 587-602.

DUNN, KEVIN M., PELLERI, DANIELLE \& MAEDER-HAN, KARIN 2011 'Attacks on Indian students: The commerce of denial in Australia', Race \& Class, vol. 52, no. 4, pp. 71-88.

DUNN, KEVIN M., et al. 2001 'Multicultural policy within local government in Australia', Urban Studies, vol. 38 , no. 13 , pp. $2477-2494$.

EQUAL OPPORTUNITY COMMISSION OF WESTERN AUSTRALIA 2009 'Accommodating Everyone'. Perth: Equal Opportunity Commission of Western Australia.

ESSED, PHILOMENA 1991 Understanding Everyday Racism: An Interdisciplinary Theory. Newbury Park: Sage Publications.

EVERY, DANIELLE \& AUGOUSTINOS, MARTHA 2008 'Constructions of Australia in pro- and anti-asylum seeker political discourse', Nations and Nationalism, vol. 14, no. 3, pp. 562-580.

FAIRCLOUGH, NORMAN 1992 Discourse and Social Change. Cambridge, UK: Polity Press.

FAIRCLOUGH, NORMAN 2003 Analysing Discourse: Textual Analysis for Social Research. New York: Routledge.

GOLDBERG, DAVID THEO 2002 The Racial State. Malden, Mass.: Blackwell Publishers.

GREEN, MEREDITH J. \& SONN, CHRISTOPHER C. 2006 'Problematising the discourses of the dominant: Whiteness and reconciliation', Journal of Community \& Applied Social Psychology, vol. 16, no. 5, pp. 379-395.

GREEN, MEREDITH J., SONN, CHRISTOPHER C. \& MATSEBULA, JABULANE 2007 'Reviewing whiteness: Theory, research, and possibilities', South African Journal of Psychology, vol. 37, no. 3, pp. $389-419$. 
GUERIN, BERNARD 2005 'Combating everyday racial discrimination without assuming racists or racism: New intervention ideas from a contextual analysis', Behavior and Social Issues, vol. 14, pp. 46-70.

HAGE, GHASSAN 1998 White Nation: Fantasies of White Supremacy in a Multicultural Society. Annandale, N.S.W.: Pluto Press.

HO, CHRISTINA 2009 'Cross-cultural collaboration: Opportunities and challenges', Cosmopolitan Civil Societies: An Interdisclipinary Journal, vol. 1, no. 2, pp. 52-62.

HO, CHRISTINA \& DREHER, TANJA 2006 'Where Has All the Anti-Racism Gone? A Critique of the 'Harmony' Framework in Australian Multicultural Policy', New Racisms, New Anti-Racisms Conference. University of Sydney.

HOWARD, JOHN 2005 'Transcript of Press Conference: Phillip Street, Sydney: 12 December 1005: Riots in Cronulla; Youth Mental Health Foundation; East Asia Summit; AWB', in Prime Minister Of Australia (ed). Sydney: Parliament of Australia.

HUMAN RIGHTS AND EQUAL OPPORTUNITY COMMISSION 1991 'Racist Violence, Report of the National Inquiry into Racist Violence in Australia'. Canberra: Australian Government Publishing Service.

HYERS, LAURI 2007 'Resisting prejudice every day: Exploring women's assertive responses to antiBlack racism, Anti-Semitism, heterosexism, and sexism', Sex Roles, vol. 56, no. 1, pp. 1-12. JAYASURIYA, LAKSIRI 2002 'Understanding Australian racism', Australian Universities Review, vol. 45, no. 1 , pp. $40-44$.

JORDAN, GLENN \& WEEDON, CHRIS 1995 'The celebration of difference and the cultural politics of racism', in Barbara Adam \& Stuart Allan (eds) Theorizing Culture: An Interdisciplinary Critique after Postmodernism. London: UCL Press Ltd.

JUPP, JAMES 1998 Immigration. Melbourne: Oxford University Press.

KAISER, CHERYL R., DYRENFORTH, PORTIA S. \& HAGIWARA, NAO 2006 'Why are attributions to discrimination interpersonally costly? A test of system- and group-justifying motivations', Personality and Social Psychology Bulletin, vol. 32, no. 11, pp. 1423-1536. 
KYMLICKA, WILL 2010 'The rise and fall of multiculturalism?: New debates on inclusion and accommodation in diverse societies', in Steven Vertovec \& Susanne Wessendorf (eds) The Multiculturalism Backlash: European Discourses, Policies and Practices. New York: Routledge.

LENTIN, ALANA 2008 'After anti-racism?', European Journal of Cultural Studies, vol. 11, no. 3, pp. 311331.

MAJOR, BRENDA, QUINTON, WENDY J. \& MCCOY, SHANNON K. 2002 'Antecedents and consequences of attributions to discrimination: Theoretical and empirical advances', in Mark Zanna (ed) Advances in Experimental Social Psychology. Academic Press.

MANSOURI, FETHI, KENNY, SUE \& STRONG, CAROL 2007 Promoting Intercultural Understanding in Australia: An Evaluation of Local Government Initiatives in Victoria. Geelong, Victoria: Deakin University.

MAROTTA, VINCE 2006 'Multicultural and multiethnic cities in Australia', in Ray Hutchinson \& Jerome Krase (eds) Ethnic Landscapes in an Urban World. Emerald Group Publishing Limited.

MCCONAHAY, JOHN 1986 'Modern racism, ambivalence and the modern racism scale', in John F. Dovidio \& Samuel L. Gaertner (eds) Prejudice, Discrimination and Racism. New York: Academic Press.

MELLOR, DAVID, et al. 2001 'The perception of racism in ambiguous scenarios', Journal of Ethnic and Migration Studies, vol. 27, no. 3, pp. 473-488.

MODOOD, TARIQ 1997 "Difference', cultural racism and anti-racism', in Pnina Werbner \& Tariq Modood (eds) Debating Cultural Hybridity: Multicultural Identities and the Politics of Anti-Racism. London; New Jersey: Zed Books.

NELSON, J. K. 2013a 'Denial of racism and its implications for local action', Discourse \& Society, vol. 24, no. 1.

NELSON, JACQUELINE K 2013b 'Denial of racism and its implications for local action', Discourse \& Society, vol. 24, no. 1, pp. 89-109.

NELSON, JACQUELINE K in press 'Place-defending and the denial of racism', Australian Journal of Social Issues, no. accepted for publication 13 December 2013. 
NELSON, JACQUELINE K. \& DUNN, KEVIN 2013 'Racism and anti-racism', in Andrew Jakubowicz \& Christina Ho (eds) 'For Those Who've Come Across the Seas': Australian Multicultural Theory, Policy and Practice. North Melbourne: Australian Scholarly Publishing.

O'BRIEN, EILEEN 2009 'From antiracism to antiracisms', Sociology Compass, vol. 3, no. 3, pp. 501-512.

PALUCK, ELIZABETH LEVY \& GREEN, DONALD P. 2009 'Prejudice reduction: What works? A review and assessment of research and practice', Annual Review of Psychology, vol. 60, no. 1, pp. 339367.

PARADIES, YIN, et al. 2009 'Building on our Strengths: A Framework to Reduce Race-Based Discrimination and Support Diversity in Victoria. Full Report'. Melbourne, Victoria: Victorian Health Promotion Foundation.

PEDERSEN, ANNE \& BARLOW, FIONA KATE 2008 'Theory to social action: A university-based strategy targeting prejudice against Aboriginal Australians', Australian Psychologist, vol. 43, no. 3, pp. 148-159.

PEDERSEN, ANNE, et al. 2000 'Attitudes toward Aboriginal Australians in city and country settings', Australian Psychologist, vol. 35, no. 2, pp. 109-117.

PEDERSEN, ANNE, et al. 2011 'How to cook rice: A review of ingredients for teaching anti-prejudice', Australian Psychologist, vol. 46, no. 1, pp. 55-63.

PEDERSEN, ANNE, WALKER, IAIN \& WISE, MIKE 2005 "'Talk does not cook rice": Beyond antiracism rhetoric to strategies for social action', Australian Psychologist, vol. 40, no. 1, pp. 20-30.

POYNTING, SCOTT 2006 'What caused the Cronulla riot?', Race \& Class, vol. 48, no. 1, pp. 85-92.

POYNTING, SCOTT \& MASON, VICTORIA 2008 'The new integrationism, the state and Islamophobia: Retreat from multiculturalism in Australia', International Journal of Law, Crime and Justice, vol. 36, no. 4, pp. 230-246.

RICHARDSON, TROYA 2011 'At the Garden Gate: Community Building Through Food: Revisiting the Critique of “Food, Folk and Fun” in Multicultural Education', The Urban Review, vol. 43, no. 1, pp. 107-123.

ROTHENBERG, PAULA 2000 'Beyond the food court: Goals and strategies for teaching multiculturalism', Feminist Teacher, vol. 13, no. 1, pp. 61-73. 
SCHMITT, MICHAEL T. \& BRANSCOMBE, NYLA R. 2002 'The meaning and consequences of perceived discrimination in disadvantaged and privileged social groups', European Review of Social Psychology, vol. 12, no. 1, pp. 167-199.

SCULLY, MAUREEN \& ROWE, MARY 2009 'Bystander training within organizations', Journal of the International Ombudsman Association, vol. 2, no. 1, pp. 1-9.

SECHRIST, GRETCHEN B., SWIM, JANET K. \& STANGOR, CHARLES 2004 'When do the stigmatized make attributions to discrimination occurring to the self and others? The roles of self-presentation and need for control', Journal of Personality and Social Psychology, vol. 87, no. 1, pp. $111-122$.

SEFA DEI, GEORGE J. 1996 'Critical perspectives in antiracism: An introduction', The Canadian Review of Sociology and Anthropology, vol. 33, no. 3, pp. 247-267.

STANGOR, CHARLES, et al. 2003 'Ask, answer, and announce: Three stages in perceiving and responding to discrimination', European Review of Social Psychology, vol. 14, pp. 277-311.

VAN DIJK, TEUN A. 1992 'Discourse and the denial of racism', Discourse and Society, vol. 3, no. 1, pp. 87118.

VASTA, ELLIE 1996 'Dialectics of domination: Racism and multiculturalism', in Ellie Vasta \& Stephen Castles (eds) The Teeth are Smiling: The Persistence of Racism in Multicultural Australia. St Leonards: Allen \& Unwin.

VASTA, ELLIE 2007 'Accomodating Diversity: Why Current Critiques of Multiculturalism Miss the Point, Working Paper No. 53'. University of Oxford: COMPAS.

VERACINI, LORENZO 2003 'Of a 'contested ground' and an 'indelible stain': A difficult reconciliation between Australian and its Aboriginal history during the 1990s and 2000s', Aboriginal History, vol. 27, pp. 224-239.

WALKER, IAIN 2001 'The changing nature of racism', in Martha Augoustinos \& Katherine Jane Reynolds (eds) Understanding Prejudice, Racism and Social Conflict. London: SAGE.

WETHERELL, MARGARET \& POTTER, JONATHAN 1992 Mapping the Language of Racism: Discourse and the Legitimation of Exploitation. New York: Columbia University Press. 
WORLEY, CLAIRE 2005 "It's not about race. It's about the community': New Labour and 'community cohesion", Critical Social Policy, vol. 25, no. 4, pp. 483-496. 
JACQUELINE NELSON is Senior Research Officer in the School of Social Sciences and Psychology at the University of Western Sydney.

ADDRESS: School of Social Sciences and Psychology, University of Western Sydney, Locked Bag 1797, Penrith NSW 2751. Email: jacqueline.nelson@uws.edu.au 